Çukurova Üniversitesi Mühendislik Mimarlık Fakültesi Dergisi, 35(2), ss. 455-468, Haziran 2020

Çukurova University Journal of the Faculty of Engineering and Architecture, 35(2), pp. 455-468, June 2020

\title{
Yedek Parça Envanter Politikasının Makina Kullanılabilirliğine Etkisini Değerlendirmeye Yönelik Bir Simülasyon Algoritması
}

\author{
Onur GÖLBAȘI ${ }^{* 1}$
}

${ }^{\text {I}}$ Orta Doğu Teknik Üniversitesi, Mühendislik Fakültesi, Maden Mühendisliği Bölümü, Ankara

Geliş tarihi: 22.04.2020 Kabul tarihi: 30.07 .2020

\section{$\ddot{\mathbf{O} z}$}

Bu çalışmada, yedek parça envanter politikasının maden makinası kullanılabilirliğine etkisini analiz edebilecek bir simülasyon algoritmasının geliştirilmesi amaçlanmıştır. Planlı üretim ve bakım duraksamaları ve makina arızalarının neden olacağı rasgele duraksamalar algoritma içerisinde dikkate alınmıştır. Her bir makina parçasının mevcut envanter miktarları ve tedarik süreçleri, uygulanan bakımonarım kararları ile birlikte değerlendirilmektedir. Böylelikle, uygulanan envanter politikasının makina kullanılabilirliğine olumsuz etkileri ölçülebilmektedir. Geliştirilen bu algoritma bir maden makinasına uygulanmış ve envanter politikası tanımlanmış on üç farklı parçasının bu makinanın kullanılabilirliğine muhtemel olumsuz etkileri detaylı şekilde incelemiş̧ir. Simülasyon sonucunda, sekiz parçaya ait yedek parça stoklama ve tedarik sürecinin, bu parçaların arızalanma davranışıyla uyumlu olmadığı ve makina kullanılabilirliğini $\% 9$ oranında azalttı̆̆ tespit edilmiştir.

Anahtar Kelimeler: Maden makinası, Yedek parça, Envanter politikası, Makina kullanılabilirliği, Simülasyon algoritmas1

\section{A Simulation Algorithm for Appraising the Effect of Spare Parts Inventory Model on Machine Availability}

\begin{abstract}
This study intends to develop a simulation algorithm that is capable of evaluating the effect of a spare parts inventory policy on the availability of mining machinery. Scheduled production and maintenance halts and the random downtimes caused by machinery failures are regarded in the algorithm. Available inventory stock levels and the active lead times are evaluated together with these downtimes. By this way, negative effects of the applied inventory policies on machinery availabilities can be measured. The developed algorithm was implemented for a mining machinery, and the inventory policies introduced for the thirteen different components of this machinery were discussed according to their potential negative effects on the machinery availability. In the results, it was detected that eight out of thirteen components have the spare part storage and procurement policies that are not accordant with the component failure behaviors, and this situation leads to a decrease of $9 \%$ in the machinery availability.
\end{abstract}

Keywords: Mining machinery, Spare parts, Inventory policy, Machinery availability, Simulation algorithm

*Sorumlu yazar (Corresponding author): Onur GÖLBAȘI, golbasi@metu.edu.tr 


\section{GíRiș}

Madencilikte fabrika tarzı bir kapalı alan üretimi yapılmamasından dolayı ve ham madde piyasası, çevre ve operasyon koşullarındaki değişimlerin üretimi önemli derece etkilemesinden ötürü, bu maden sahalarındaki işletme gider kalemlerinin ve plansız üretim kayıplarının süreğen olarak denetlenmesi gerekmektedir. Bu husus, madencilik faaliyetlerinin devamlılığı ve verimliliği açısından kritik öneme sahiptir.

İşletme maliyet kalemleri arasında yer alan bakımonarım giderleri, en kontrol edilebilir giderlerdir. $\mathrm{Bu}$ faaliyetler, makina kullanılabilirliğini istenilen düzeyde tutmayı amaçlayan ve arızalara yönelik düzeltici ve önleyici eylemler sunan faaliyetlerdir. Burada bahsi geçen kullanılabilirlik terimi, sistemlerin hedef çalışma süresinin aslında ne kadarında çalışabildiklerini gösteren bir yüzdesel terimdir. Bakım onarım ve destekleyici eylemler, makinanın kullanılabilirliğine en büyük etkiyi yapan faktörlerdir. $\mathrm{Bu}$ eylemlerinin yerine getirilmesinde yükümlülük ve sorumlulukları olan kişilerin belirlenmesi, birimler arası koordinasyon, yedek parça depolanması ile ilgili kararlar ve bakım-onarım eylemlerin yerine getirilme sıklığ gibi hususlar entegre bir politika içerisinde yer almaktadır. Madenlerdeki uygulamalar incelendiği zaman, bu politikaların içeriklerinin genellikle sübjektif deneyimlere göre belirlendiği ve değişen makina ve üretim koşullarına göre güncelliklerini koruyamadıkları görülmektedir. Maden koşullarına göre uygun olmayan bir bakım-onarım politikası, hem makina parçalarının arıza sıklığının artışına hem de yedek parça temini ile sıkıntılara neden olacaktır.

Yedek parça envanter yönetimi, bakım-onarım politikasının ayrılmaz bir parçasıdır. Bu yönetim sisteminin içeriği oluşturulurken, her bir yedek parçanın geçmiş talep sıklığ 1 , parça kritikliği, bu parçanın bulunduğu makinanın üretim içerisindeki önemi, tedarik süresi, potansiyel tedarikçiler ve parçanın sınıflandırması gibi faktörler göz önüne alınmalıdır. Yedek parça tedarik süreci parçalara göre farklılık gösterebilir. Bu süreçler, ilgili yedek parçanın tekrardan sipariş için gerekli sayıya inmesi, düzenli aralıklarla temin edilmesi, düzensiz aralıklarla tahmine dayalı tedarik edilmesi veya bunların kombinasyonu şeklinde yürütülebilir.

Bir madende uygulanan yedek parça envanter politikası, kullanılan makinalara, bu makinaların faaliyet ve bakım-onarım aktivitelerine ve üretimin birim değerine göre madene özgü olarak oluşturulmalıdır. Bu bağlamda, uygun olamayan bir yedek parça politikası, yedek parça eksikliğinden kaynaklı olarak bakım-onarım duraksamalarının uzamasına ve fazladan üretim kayıplarına neden olabilir. Diğer bir durumda, yedek parçaların gereğinden fazla depolanması, yüksek kapital çıkışına, depolama alanı sorunlarına ve parçaların malzeme özelliklerinde zamana bağlı bozulmalara sebep olabilir. $\mathrm{Bu}$ nedenle, yedek parça temin aralıkları ve miktarları, stok fazlasını engelleyecek ama üretimde fazladan duraksamalara da yol açmayacak şekilde bir finansal denge içerisinde belirlenmesi gerekir. Ancak, üretimin birim zamandaki değerinin çok yüksek olduğu ve/veya üretim hızının planlananın çok üzerine çıkması gereken durumlarda, makina kullanılabilirliği daha büyük önem kazanabilir.

Literatürde yedek parça yönetimine dair çalışmalar, ilk tedarik aşaması, üretim aşaması ve üretim sonrası süreç olmak üzere 3 farklı fazda ele alınmaktadır. $\mathrm{Bu}$ araştırmalar genel itibariyle, yedek parçaların sınıflandırılması, tedarik aralığı, tedarik miktarı, tedarikçi seçimi, yeniden sipariş düzeyi ve güvenlik stoku gibi konularda optimizasyon çalışması ve/veya mevcut durum analizi sunmaktadırlar. İlgili optimazyon çalışmalarında amaç fonksiyonu, yedek parça siparişi, bakım-onarım, depolama ve üretim kayıplarından meydana gelecek masrafların hepsinin veya bir kısmının toplamını en aza indirmeyi amaçlamaktadır [1]. Bu bağlamda, bir envanter politikasının dinamikleri, uygulanan önleyici bakım faaliyetleri, çalışır parçaların türleri ve adetleri, bu parçaların zaman bağlı aşınma ve yıpranma davranışları ve tedarikçi profiline göre değişiklik gösterebilir [2]. Üretim sektörlerinde, $(\mathrm{Q}, \mathrm{R}),(\mathrm{s}, \mathrm{S}),(\mathrm{s}, \mathrm{Q})$, ve $(\mathrm{R}, \mathrm{S})$. yedek parça envanter politikaları sıklıkla görülmektedir. $(\mathrm{Q}, \mathrm{R})$ envanter politikası, yeniden sipariş verilmesi için parça bazlı alt limit adeti (R) ve bu limite 
gelindiğinde kaç adet parça siparişinde bulunulacağını belirtir [3]. (s, S) envanter politikası, güvenli stok seviyesinin (s) altına inmeyecek şekilde, depodaki parça adetlerini tekrardan $\mathrm{S}$ düzeyine çıkarılmasını amaçlamaktadır [4]. (s, Q) modelinde güvenli stok seviyesi, sabit tedarik adeti ile ele alınmaktadır [5]. $(\mathrm{R}, \mathrm{S})$ modelindeki sipariş adeti, yeniden sipariş zamanına ulaşıldığında, envanter seviyesi $\mathrm{S}$ değerine çekecek şekilde işletilmektedir. $\mathrm{Bu}$ modellere ek olarak, sabit sipariş aralığının (T)'da dahil edildiği $(\mathrm{S}, \mathrm{T})$ ve $(\mathrm{s}, \mathrm{S}, \mathrm{T})$ gibi modeller de üretim sektörlerinde gözlemlenmektedir [6]. Mevcut çalışma, madencilikte sıklıkla görülen (Q, R) politikasını dikkate almaktadır.

Geçmişte yapılmış çalışmalar incelendiğinde, madenciliğe yönelik yedek parça araştırmalarının yeterli seviyede olmadığı gözlenmektedir. $\mathrm{Bu}$ noktada, Ghodrati ve Kumar [7] tamir edilemez yani arıza durumunda değiştirilmesi gereken parçaların yıllık gerekli stok seviyelerinin tayininde çalışma ortamının etkisini incelemiştir. $\mathrm{Bu}$ çalışma içerisinde, bir tekerli yükleyicinin hidrolik fren pompası için çevresel faktörlerin y1llı stok seviyesine etkisi orantılı tehlike modeli ile analiz edilmiştir. Ortam değişkenleri olarak operatör verimliliği, bakım-onarım ekibinin verimliliği, hidrolik yağ kalitesi, iklim koşulları ve fiziki çevresel faktörler ele alınmıştır. Bu değişkenler dikkate alınarak ve alınmayarak yapılan iki farklı analizin sonucunda, yıllık gereken envanter sayıları sırasıyla 12 ve 8 olarak hesaplanmıştır. Böylelikle, harici faktörlerin envanter kararlarında ne kadar etkin olabileceği gösterilmiştir. Ghodrati ve arkadaşları [8], yedek parçalar için ilgili alınabilecek kararların risklerini olay ağacı analizi ile incelemiş ve oluşturulan yöntemi bir demir madenindeki yükleyici için uygulanmışlardır. Yedek parça politikası belirlerken çalışma ortamının dikkate alınmaması, yetersiz yedek parça desteği, yetersiz yedek parça tahmini, yedek parça eksikliği, fazla makina duraksaması, üretim kaybı ve ekonomik kayıp gibi hususların gerçekleşme ve gerçekleşmeme olasılık değerlerini dikkate alarak oluşabilecek tüm kombine etkiler incelemişlerdir. Olasılıksal çarpımlar neticesinde oluşan değerler, yıkıcı etki, zor durum ve güvenli durum başlıkları altında ele alınmış, envanter tahmininde en büyük etkiyi sunacak faktörler belirlenmiştir. Wang ve arkadaşları [9], düzenli bakım denetim aralığı, azami stok seviyesi, yeniden sipariş adeti ve önleyici parça değiştirme eşik değeri gibi faktörleri bir araya getiren, maliyeti minimize etmeyi amaçlayan bir envanter optimizasyon modeli üzerine çalışmışlardır. Model içerisinde makina durumunu izleme indikatörleri ve yedek parça politikasının birlikte kullanılabileceği ve böylelikle daha verimli envanter politikaları oluşturulabileceği belirtilmiştir. Çalışma kapsamında gerçekleştirilen uygulamada, maden taşıma kamyonlarının motor yağları içerisinde biriken demir ve tortu değerlerinin, motorun yıpranması hakkında bilgi verebileceği ve motor ile ilgili bir yedek parça politikası oluşturulurken bu bilgiden yararlanılabileceği iddia edilmiştir. Louit ve arkadaşları [10], yedek parça stok seviyelerinin optimizasyonunu farklı türde kriterlerle sağlayabilen bir model geliştirmişlerdir. Model içerisindeki kriterler, i) maliyetin minimize edilmesi, ii) makina kullanılabilirliğinin maksimize edilmesi, iii) anlık güvenilirlik seviyesinin maksimize edilmesi ve iv) zaman aralığı güvenilirlik seviyesinin maksimize edilmesi şeklindedir. Modelin, belirsiz bir arızalanma davranışına sahip hem tamir edilemeyen hem de tamir edilebilir parçaların envanter modellemesinde kullanılabileceği belirtilmiştir. Çalışma, bir bakır madenindeki taşıma kamyon filosu için tamir edilebilir bir parçaya uygulanmıştır. Yukarıdaki optimizasyon kriterlerine göre, bu parça için optimum envanter seviyesi sirasıyla $14,6,10$ ve 15 olarak bulunmuştur. Parçaya uygun kriter seçilirken, ilgili makinanın üretime doğrudan veya dolaylı etkileri ve oluşan toleranslar dikkate alınmalıdır. Martinez ve arkadaşları [11], yedek parça yönetimi ve üretim kaybına yönelik sigorta politikasını birleştiren bir ortak optimizasyon modeli geliştirmiştir. Bu model ile yedek parça maliyeti ve stokta yedek parça olmaması durumunda yaşanılacak üretim kaybı riski için bir dengeleme analizi yapılmıştır. Geliştirilen model, madenlerde kullanılan hidrolik kazıcının bir tamir edilemez parçası için uygulanmıştır. Zhang ve arkadaşları [12] ortak bir yedek parça deposu kullanan madencilik şirketleri için, toplam satın alma, 
depolama, sipariş ve üretim kaybı maliyetini azaltacak bir model üzerine çalışmışlardır. $\mathrm{Bu}$ modelle, ortak paylaşımlı bir depolama merkezi kullanan üç altın maden şirketine yönelik bir uygulama yapılmıştır. Çalışma içerisinde, şirketlerin yedek parça envanter yönetimleri paylaşımlı merkez tarafından yürütülmekte ve parçaların adetleri kritik seviyelere indiği zaman, merkezi bir satın alma prosedürü uygulanmaktadır. Qarahasanlou ve arkadaşları [13], kamyon modeli, tekerlerin aks konumları, teker özellikleri, yağış ve sıcaklık değerleri gibi çevresel ve teknik eş değişkenleri içerecek şekilde, bir bakır madenindeki taşıma kamyonları için yedek teker sayısı kestirim modeli geliştirmişlerdir. $\mathrm{Bu}$ bağlamda, dört farklı kamyon markası, ön ve arka akslar olmak üzere iki farklı aks konumu, $-3{ }^{\circ} \mathrm{C}$ ve $+16{ }^{\circ} \mathrm{C}$ arası bir sicaklık aralığı ve $0,26 \mathrm{~mm}$ ve 1,97 mm arası bir yağ ${ }_{1 S ̧}$ aralığı hesaba katılarak, 12 farklı katmanda eş değişkenler listelenmiş ve bu değişkenlerin farklı etkileşimlerinde açığa çıkacak teker gereksinimleri analiz edilmiştir.

Maden makinaları için envanter modeli oluştururken, arıza davranışının tümevarımlı bir yaklaşımla ve makina parçaları arası etkileşim de dikkate alınarak oluşturulması gerekmektedir. $\mathrm{Bu}$ çalışma, mevcut bir yedek parça politikasının üretim duraksamalarına etkisini, başka bir deyişle arıza anında stokta yedek parça olmamasının makina kullanılabilirliği üzerine etkisini, bir simülasyon algoritması yardımıyla incelemektedir. $\mathrm{Bu}$ algoritma, sistemin çalışma profilini, bakımonarım davranışını ve makina parçalarının üretime etkisini stokastik olarak ele almaktadır. Rastlantısallığın bu şekilde dâhil edildiği makina kullanılabilirlik modeline yedek parça stok kontrolü modeli adapte edilmektedir. Böylelikle, algoritma süreğen bir şekilde, makina arıza davranışını, stoktaki mevcut yedek parça sayılarını ve tedarik aşamasında olan yedek parçaların geliş sürelerini kısa zaman aralıklarıyla monitör edebilmektedir. Geliştirilen simülasyon algoritmas1, bir maden sahasına faal olarak kullanılan kazıcı makinaya uygulanmıştır.

Mevcut çalışma beş ana kısımdan oluşmaktadır. Giriş bölümünü takiben, algoritmanın geliştirilmesinde uygulanan yöntem Bölüm 2'de ele alınmaktadır. Örnek uygulama, Bölüm 3'de sunulmaktadır. Çalışma bulgularına yönelik değerlendirmeler Bölüm 4'de tartışılmaktadır. Çalışma içeriği ve sonuçlarının özeti Bölüm 5'de verilmektedir.

\section{YÖNTEM}

\subsection{Varsayımlar}

$\mathrm{Bu}$ çalışma, uygulanan yedek parça politikalarının maden makinalarının kullanılabilirliği üzerine negatif etkilerini analiz edebilen bir simülasyon algoritması geliştirmeyi amaçlamaktadır. Algoritma varsayımları şu şekildedir:

i. Makina parçaları arasında fonksiyonel olarak seri bir ilişki olduğu, yani herhangi bir parçadaki arızanın tüm makina üretimini durdurabileceği varsayılmıştır.

ii. Makinaların, planlı duraksamalar ve arıza sonrası gerçekleştirilen düzeltici bakım faaliyetleri dışında süreğen olarak çalıştığ 1 düşünülmektedir.

iii. Bakım-onarım elemanlarının sayıları, görev paylaşımları, yeterliliklerine yönelik bir kısitlama yoktur. Yani, bir arıza meydana geldiğinde, ilk çağrıdan arızanın giderilip parçanın test edilmesine kadarki süreçte bakım-onarım ekibi ve organizasyonunda bir yetersizlik veya gecikme olmadığ düşünülmektedir.

iv. Algoritma içerisinde, maden sahalarında sıklıklar görülen yeniden sipariş için asgari stok sayısı politikası temel alınmaktadır. Bu politikaya göre, envanterde yani maden sahasındaki depoda bulunan bir yedek parça belirli bir sayının altına indiğinde, satın alma süreci başlatılır. Bu sürece göre belirli sayıda parça bir tedarik süresi içerisinde tedarikçi tarafından maden sahasına ulaştırılır.

v. Algoritma, aynı sistem için eş zamanlı şekilde iki farklı simülasyona olanak verir. Birinci simülasyonda, makinanın parça bazlı normal 
arızalanma davranışı, uygulanan bakımonarım politikası ve önceden belirlenmiş yönetimsel duraksamalar için matematiksel ve rasgele ilişkiler kurulur. Yedek parça politikası, model içerisinde bir kısıt olarak alınmayarak makina kullanılabilirliği ve üretim kayıpları hesaplanır. $\mathrm{Bu}$ durum, çalışma içerisinde ideal yedek parça politikası olarak adlandırılacaktır. İkinci modelde, birinci modele ek olarak yedek parça politikası da aktif hale getirilir. Yedek parça politikası entegre edilmiş bu model için tekrardan üretim kayıpları ve makina kullanılabilirliği hesaplanır. İki modelin sonuçları arasındaki farklılığın, yedek parça envanter politikasının neden olduğu fazladan duraksamalardan kaynaklı olduğu varsayılır.

\subsection{Algoritmanın Geliştirilmesi}

Geliştirilen algoritma, şu alt aşamaların birbirine entegrasyonu ile çalışmaktadır: a) Makinanın çalışma sürelerinin ve arızadan kaynaklı duraksama sürelerinin Monte Carlo yöntemi ile rasgele atanmasının sağlanması, b) planlı duraksamaların algoritmaya dâhil edilmesi, c) modelin gerçek zaman çizelgesine adapte edilmesi, d) her bakım-onarım faaliyeti kararından sonra yedek parçanın stok durumunun değerlendirilmesi, e) gerekli yedek parçanın stokta olmadığ 1 bir durum tespit edildiğinde, tedarik sürecinin aktifliğinin ve kalan tedarik süresinin analiz edilmesi. Çalışma ve arıza süreleri Monte Carlo yöntemi ile tayin edilmeden önce, bu sürelere ait dağılımların belirlenmiş olması gerekmektedir. İlgili makinanın bakım onarım davranışına yönelik bir geçmiş veri mevcut değil ise, arızalar arası süreler ve arıza süreleri için en iyimser, en kötümser ve en beklenen değerler tahmin edilerek üçgensel bir dağılımlar oluşturulabilir. $\mathrm{Bu}$ tahminlerde, imalatçı firma önerilerinden ve sektördeki uzman görüşlerinden yararlanılabilir. Eğer geçmiş veriler mevcut ise, bu verileri en iyi temsil eden dağılımlar belirlenir. Geliştirilen algoritma, Reliasoft Reno [14], programı içerisinde çalıştırılmıştır. Elde edilmiş dağılımlar bu programa tanıtılmış ve dağılımların doğasına uygun olarak Monte Carlo yöntemi ile tekrarlayan rassal değerler türetilmesi sağlanmıştır. Bir simulasyon içerisinde Monte Carlo ile rassal değerler atanmasına yönelik detaylar [15]'den incelenebilir. Algoritma kapsamındaki karar mekanizmalarının mateimatiksel gösterimi Çizelge 1'de verilmektedir. Algoritmanın genel mantık akışı Şekil 1'de gösterilmiştir.

Şekil 1 ve Çizgelge 1'de belirtildiği üzere, simülasyon, gözlem süresinin $\left(t_{t}\right)$ belirlenmesiyle başlar. Gözlem süresi, her bir simülasyon için makina davranışının izlenileceği periyodu tanımlar. Örneğin, ilgili makinanın yıllık kullanılabilirlik değerini bulabilmek için $t_{t}$ değeri 8.766 saat olarak alınabilir. Sonrasında, makinanın durumu, zaman artışı değerine $(\Delta \mathrm{t})$ göre güncellenen her bir aktif sürede (t) algoritma tarafından analiz edilir. Düzenli makina bakım denetimleri, vardiya değişimleri, geniş makina revizyonları ve bunlar gibi planlı duraksamalar algoritma tarafindan zaman çizelgesine yerleştirilir. Her bir parçanın arızalanmadan çalışabilirlik süresi $\left(\mathrm{TF}_{\mathrm{i}}\right)$ rasgele olarak atanır. Simülasyon içindeki zaman çizelgesi sıfirdan başlatılır ve her seferinde $(\Delta \mathrm{t})$ değeri kadar arttırılarak, hedef gözlem süresine $\left(\mathrm{t}_{\mathrm{t}}\right)$ kadar aşama aşama sistemin durumu incelenir.

Simülasyon zamanı $\Delta t$ kadar arttırıldığı her noktada, sistemin planlı bir duraksamaya veya bir bakım-onarıma maruz kalıp kalmadığı sistemin her bir $i$ bileşeni için tespit edilir. Bakım-onarımın tespit edildiği noktalar, özellikle tamir edilemez parçaların yedek parça ihtiyacına işaret eder. Bu noktada, sisteme tanımlı herhangi bir aktif tedarik sürecinin olup olmadığını $\mathrm{TR}_{\mathrm{i}}$ değeri yardımıyla algoritma tarafından tespit eder. Tedarik sürecinin aktif olduğu durumlarda, bu değişken sıfir dışında bir değer alır ve algoritma ilgili yedek parçanın ne zaman madene ulaşacağını hesaplar. Parçanın madene geliş süresi aktif simülasyon süresinden $(\mathrm{t})$ ötedeyse, mevcut envanter sayısında $\left(\mathrm{S}_{\mathrm{i}}\right)$ bir değişiklik olmaz. Simülasyon süresi tedarik sürecinin tamamlandığını tespit ederse, ilgili parçanın mevcut envanter sayısı sipariş adeti $\left(\mathrm{O}_{\mathrm{i}}\right)$ kadar arttırılır ve ilgili $\mathrm{TR}_{\mathrm{i}}$ değeri aktif bir tedarik süreci olmadığı için sıfırlanır. 


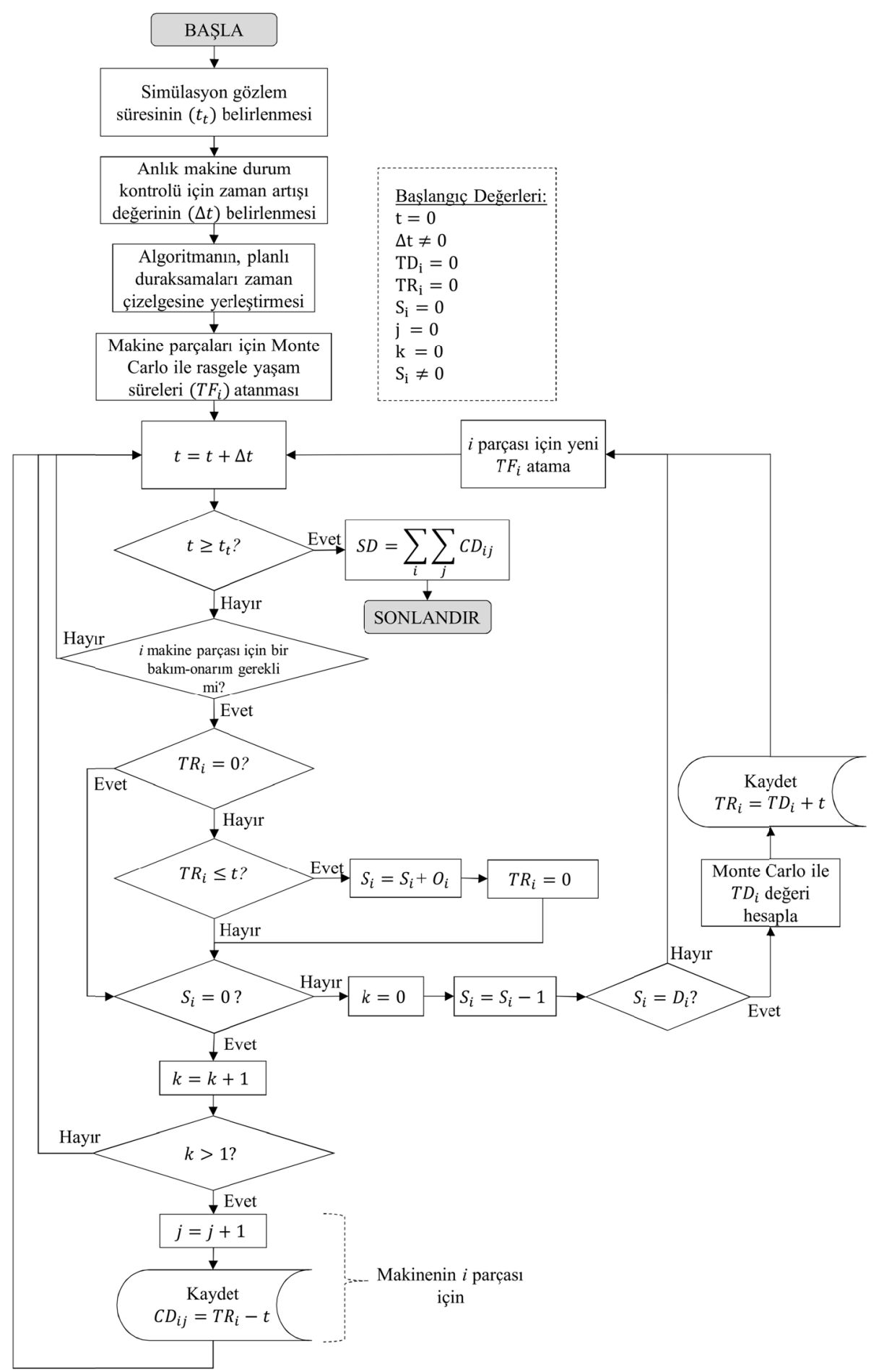

Şekil 1. Algoritmanın mantık akışı 
Çizelge 1. Algoritma içerisindeki karar mekanizmaları

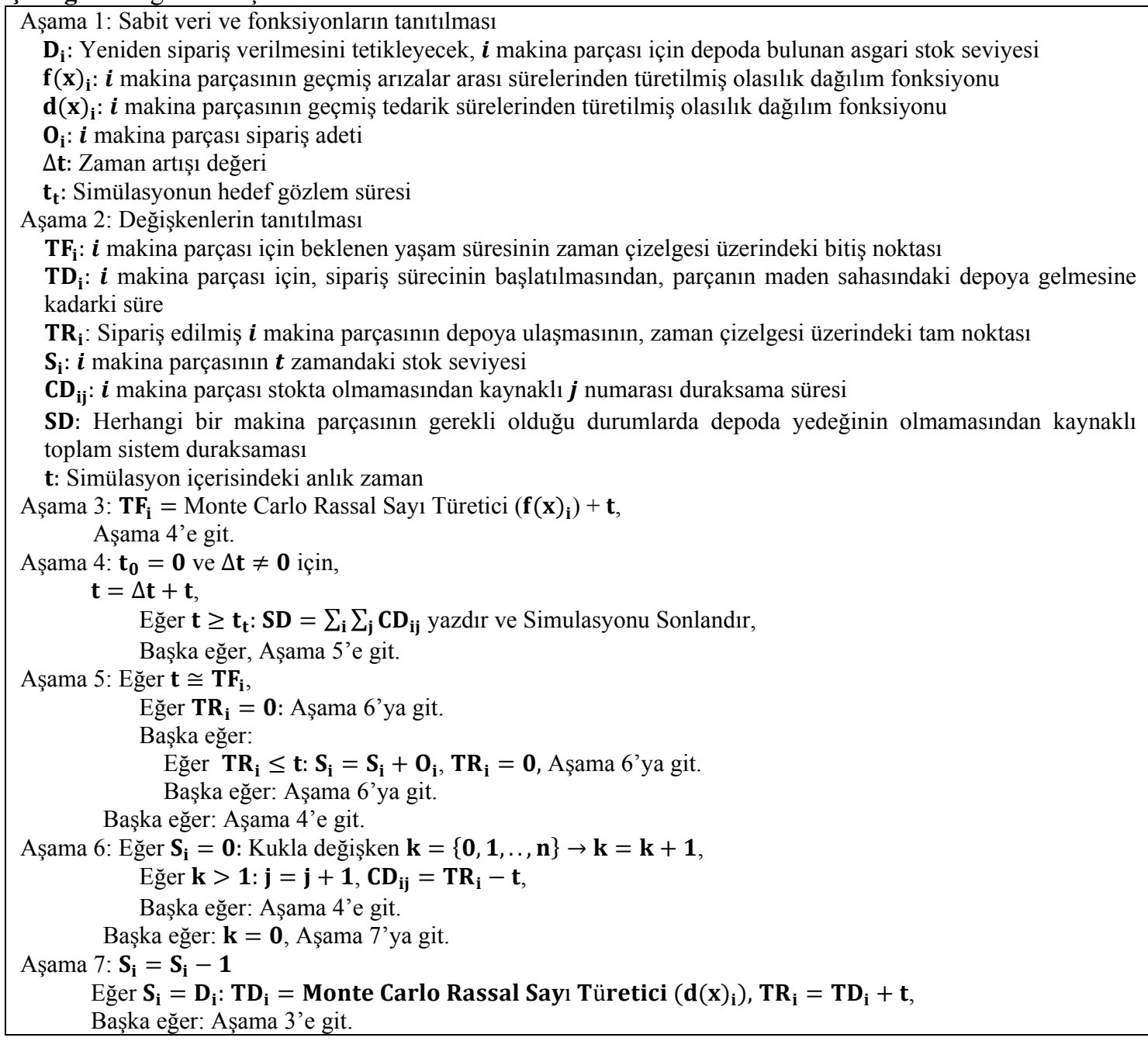

Bakım-onarım gereksinimi tespit edilen parçalar için algoritma içerisinde envanter modülü aktif duruma gelir. Bakım-onarım zamanlarının belirlenmesinde, parçaların olasılık dağılım fonksiyonlarından türetilen beklenen yaşam süreleri $\left(\mathrm{TF}_{\mathrm{i}}\right)$ baz alınır ve algoritma tahmini arıza noktaları zaman çizelgesine yerleştirilir. Simülasyonun anlık zaman değeri $(t)$ eğer bu arızalanma noktalarına yaklaşmışsa, simülasyon kendi içerisinde önleyici veya düzeltici bakım kararından birini alır. Güvenilirlik bazlı bakımonarım kararlarına ait detaylar, Golbasi ve Demirel [16]'in yaptığ onarım kararı alındığında, stok seviyesi $\left(\mathrm{S}_{\mathrm{i}}\right)$ eğer sıfırdan büyük ise, parçanın envanterden çıkışı gerçekleştirilir . Bu çıkıştan sonra stokta kalan parça adeti yeniden sipariş vermeyi tetikleyecek seviyeye $\left(D_{i}\right)$ inmişse eş zamanlı olarak tedarik süreci başlatılır. $\mathrm{Bu}$ sürecin başlandığı noktadan, parçanın maden sahasına gelmesine kadarki süre $\left(\mathrm{TD}_{\mathrm{i}}\right)$ üçgensel dağılımla rasgele atanır. $\mathrm{Bu}$ dağılım türü, tedarik sürecine dair en iyimser en kötümser ve beklenen tedarik sürelerin sübjektif olarak öğrenilip kullanılabileceği pratik bir dağılım türüdür. Atanan sipariş süresi aktif zamana eklenerek, zaman çizelgesi üzerinde siparişin madene ulaşacağı nokta $\left(\mathrm{TR}_{\mathrm{i}}\right)$ belirlenir. 
Bakım-onarım eylemi için gereken parça, tedarik süreci bitmediğinden ötürü depoda mevcut değil ise, parça için bakım-onarım yapılamaz. $\mathrm{Bu}$ durumda, beklenen tedarik zamanı $\left(\mathrm{TR}_{\mathrm{i}}\right)$ ve bakımonarım tespitinin yapıldığı zaman arasındaki süre farkı kadar $\left(\mathrm{CD}_{\mathrm{ij}}\right)$, fazladan bir üretim duraksaması yaşanır. Bu tarz bir duraksamaya bakım-onarım için harcanan süre dâhil edilmez. Algoritma içerisinde bu fazladan duraksama noktaları analiz edilerek, envanter modelinin makina kullanılabilirliğine muhtemel negatif etkileri değerlendirilmektedir. Bu bağlamda, simülasyon içerisinde eş zaman olarak iki farklı analiz yürütülür. Birinci durumda, yedek parça politikası pasif duruma getirilir ve bir model kisitı olarak değerlendirilmez. Bu durumdaki makina duruşları yönetimsel ve bakım-onarım bazlı duruşlardır. İkinci durum ise yedek parça politikası aktif hale getirilir. $\mathrm{Bu}$ durumda, birinci modele ek olarak yedek parça stok seviyeleri, tedarik süreçleri ve bakım-onarım arasındaki dinamik etkileşim de dikkate alınır. Her iki durum için makina kullanılabilirliği ve üretim kayıpları hesaplanır. İki analiz arasındaki makina kullanılabilirliği ve üretim kaybı farkı, uygulanan yedek parça envanter politikasının makina kullanılabilirliğine muhtemel negatif etkisini ortaya koyar.

\section{3. ÖRNEK UYGULAMA}

Geliştirilen algoritmanın etkinliğini bir örnek uygulama ile değerlendirilmiștir. Bu bağlamda, 30 $\mathrm{m}^{3}$ kepçe kapasitesi olan bir çekme kepçeli yerkazar hedef sistem olarak seçilmiştir. Sistemin parçalarının çalışma ve bozulma davranış fonksiyonları, Gölbaşı ve Demirel [16] tarafından gerçekleştirilen bir çalışmadan temin edilmiştir. Aynı zamanda, birim üretim değerine dair veriler de aynı çalışmadan sağlanmıştır. Sistemin bütünsel çalışma davranışını incelemek için, düzenli bakımonarım aralıkları (haftalık düzenli bakım-onarım denetimleri) ve vardiya değiş̧imleri, planlı duraksamalar olarak algoritmaya dahil edilmiştir. $\mathrm{Bu}$ örnek uygulamanın kapsamı şu şekildedir:

i. Makinanın yedek parçaları için ilk stok seviyeleri belirlidir. Makina, bu stok seviyeleri ile operasyona başlar. Belirli bir parçanın stoktaki adeti belirli bir eşiğin altına indiğinde, ilgili parça için tedarik süreci başlatılır (Çizelge 2).

ii. Makinada, arızalanma geçmiși olan 30 ana parça olduğu belirtilmiştir. Mevcut çalışmada, bu bileșenlerin sadece on üç tanesi için envanter modeli tanımlanmış, geriye kalan bileşenler için herhangi bir yedek parça kısıtı girilmemiştir. Bunun nedeni, geriye kalan bileşenlerin arıza verilerinde yeterince tekli parça tanımlanmamış olmasıdır. Örneğin, makina dairesi bileşenleri motor, jeneratör ve yağlama ünitesi olarak belirtilmiștir. Motorda bir arıza gerçekleştiğinde genellikle motorun tamamı değil motor içerisinde bir parçaya bakım yapılmaktadır. Ancak, geçmiş verilerinde bu tarz tüm arızalar motor olarak tanımlanmıştır. Bu sebeple, tek parça olarak tanımlanmış ve bir bakım-onarım faaliyetinde yenisi ile değiştirilme ihtimali yüksek olan parçalar üzerine odaklanılmıştır. Çünkü bu parçaların bakım-onarım faaliyetleri ile envanter stok seviyeleri arasında doğrudan bir ilişki mevcuttur.

iii. Tanımlanmış bu on üç parçanın bakım-onarım zamanlarında, meydana gelebilecek bir yedek parça yokluğu tüm sistemin üretimini durduracaktır.

iv. Simülasyon içerisindeki hedef gözlem süresi $\left(t_{t}\right)$ iki sene yani 17.532 saat olarak belirlenmiştir. Böylelikle, uzun aralıklı arızalanma davranışı gösteren parçaların profilinin daha iyi gözlenmesi amaçlanmıştır. Toplam simülasyon sayısı 1000 olarak alınmıştır.

v. Bölüm-2'de detayları anlatılan algoritma, iki farklı durum için çalıştırılmışıır. Birinci durumda, parçaların envanterdeki stok seviyeleri için yüksek değerler girilip parçanın stokta kalmama etkisi elimine edilmiştir. Bu durum için bir sistem kullanılabilirlik oranı bulunmuş ve İdeal Envanter Politikası olarak adlandırılmıştır. İkinci durumda ise algoritma, sahada uygulanan ilk stok seviyesi ve tedarik sürecinin başlangıcını tetikleyecek asgari stok 
seviyesi için çalıştırılmıştır. Bu durum ise Mevcut Envanter Politikası olarak isimlendirilmiștir. İkinci durum geçerli envanter girdileri, makinanın çalıştırıldığı sahadan temin edilmiş ve Çizelge 2'de gösterilmiştir.

Çizelge 2. Mevcut envanter politikası

\begin{tabular}{|c|l|c|c|c|l|c|c|}
\hline $\begin{array}{c}\text { Parça } \\
\text { Kodu }\end{array}$ & $\begin{array}{c}\text { Parça } \\
\text { Açılaması }\end{array}$ & $\begin{array}{c}\text { İlk Stok } \\
\text { Adeti }\end{array}$ & $\begin{array}{c}\text { Yeniden Sipariş } \\
\text { Adeti }\end{array}$ & $\begin{array}{c}\text { Parça } \\
\text { Kodu }\end{array}$ & $\begin{array}{c}\text { Parça } \\
\text { Açıklaması }\end{array}$ & $\begin{array}{c}\text { İlk Stok } \\
\text { Adeti }\end{array}$ & $\begin{array}{c}\text { Yeniden Sipariş } \\
\text { Adeti }\end{array}$ \\
\hline BU2 & Kepçe Zinciri & 4 & 2 & HO1 & Kaldırış Freni & 4 & 2 \\
\hline BU3 & Kepçe Dişi & 10 & 5 & HO2 & $\begin{array}{l}\text { Kaldırı̧ Halatı } \\
\text { Aparatı }\end{array}$ & 4 & 2 \\
\hline BU4 & Kepçe Pimi & 24 & 12 & RI1 & Terazi Soketi & 8 & 4 \\
\hline BU5 & Kepçe Mapas1 & 14 & 7 & RI2 & Terazi Mapas1 & 8 & 4 \\
\hline DR1 & Çekiş Zinciri & 4 & 2 & RI5 & Terazi Makaras1 & 4 & 2 \\
\hline DR2 & Çekiş Mapas1 & 8 & 4 & & & & \\
\hline DR3 & $\begin{array}{l}\text { Çekiş Halat } \\
\text { Aparatı }\end{array}$ & 4 & 2 & & & & \\
\hline DR6 & Çekiş Soketi & 4 & 2 & & & & \\
\hline
\end{tabular}

Hedef gözlem süresi $\left(t_{t}\right)$ olarak belirlenen 17.532 saat boyunca, simülasyon süresi kademeli olarak attırılmıştır. Her bir süre artışında $\mathrm{t}[\mathrm{i}]$ ve $\mathrm{t}[\mathrm{i}-1]$ arasındaki beklenen makina kullanılabilirlik değeri 1000 adet simülasyonun sunucu olarak ölçülmüştür (Şekil 2).
İdeal envanter politikasına sahip makinada, mevcut envanter politikasına göre daha stabil sonuçlar elde edilmiştir. Tüm anlık kullanılabilirlik değerleri hesaba katıldığında, beklenen kullanılabilirlik değerleri, ideal ve mevcut envanter politikaları için sırasıyla $\% 77$ ve $\% 68$ olduğu tespit edilmiştir.

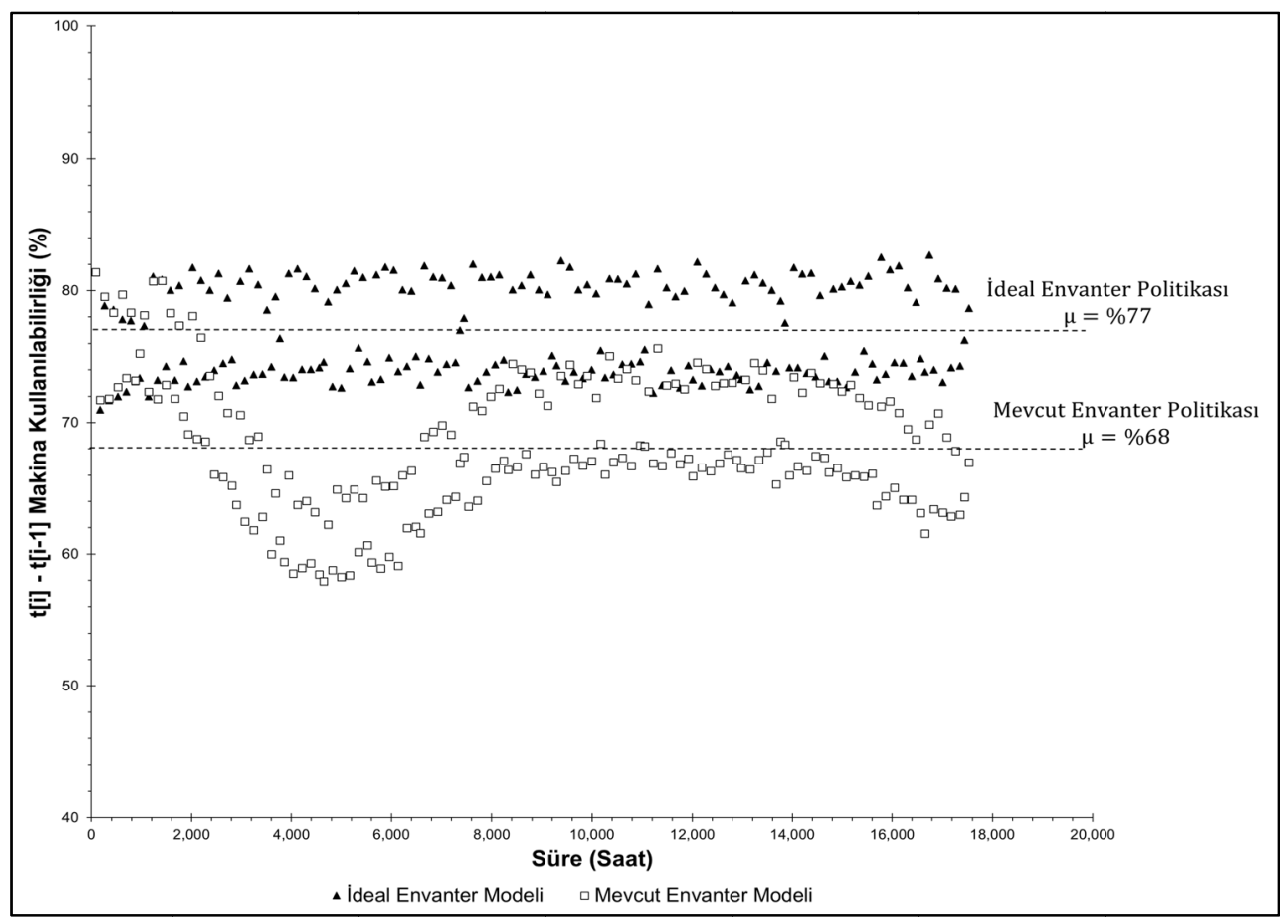

Şekil 2. Envanter politikalarına göre anlık kullanılabilirlik değerleri 
Şekil 2'de gözlemlenen dalgalanma, mevcut politikanın makina kullanılabilirliğine belirgin etkileri olabileceğini göstermektedir. Makina kullanılabilirliği ve arıza sayılarındaki belirsizlik değerleri Şekil 3'de verilmiştir. İdeal bir envanter politikası ile makina için \%95 güven aralığında $\% 88$ ve $\% 66$ arası bir kullanılabilirlik beklenirken, mevcut politika ile bu aralık \%87 ve \%49 arasında değişmektedir. Mevcut politikanın, makina kullanılabilirliğinde yüksek bir belirsizliğe neden olabileceği, standart sapma değerleri $(\sigma)$ arasındaki yüksek farklılıktan da anlaşılmaktadır. 17.532 saat boyunca gözlenmesi muhtemel arıza sayıları, ideal ve mevcut politikalar için sırasıyla 219 ve 195 olarak tespit edilmiştir. Mevcut politikada, duraksamalar artmış ve makinanın çalışabilirlik süresi kısaldığı için daha az arıza tespit edilmiştir. $\mathrm{Bu}$ çıkarımların yani sıra, envanter politikası tanımlanmış on üç makina parçanın duraksamalara etkileri Şekil 4'de verilmektedir. Beş parçada envanter tabanlı bir duraksama gözlenmezken, diğger sekiz parçada $\% 1,2$ ve $\% 49,7$ arası değişen duraksama artışları tespit edilmiştir. Makinanın kullanılabilirliğindeki ortalama $\% 9$ oranındaki azalmanın, bu sekiz parçanın envanter politikasının, makinanın arızalanma davranışına uyumsuz olmasından kaynaklandığı belirlenmiştir. Özellikle, DR3 (çekiş halat aparatı), BU4 (kepçe pimi), DR1 (çekiş zinciri) ve HO1 (kaldırış freni) gibi parçaların mevcut envanter politikaları, bu parçaların arıza bazlı beklenen duraksamalarımı yaklaşık $\% 20$ ve üzerinde arttırmıştır.

Özetlemek gerekirse, envanter modelindeki parça bazlı iyileştirmelerle yaklaşık olarak \%9 oranında bir kullanılabilirlik artışı sağlanabilir. $\mathrm{Bu}$ tahminlerin güvenilirliği ve uygulanabilirliği, makinanın tüm parçalarının tanımlandığı bütünsel bir envanter modelinin oluşturulması ve bakımonarım elamanı yetkinlik ve yeterlilik bilgilerinin bu modele tanıtılmasına bağlı olarak değişebilir.

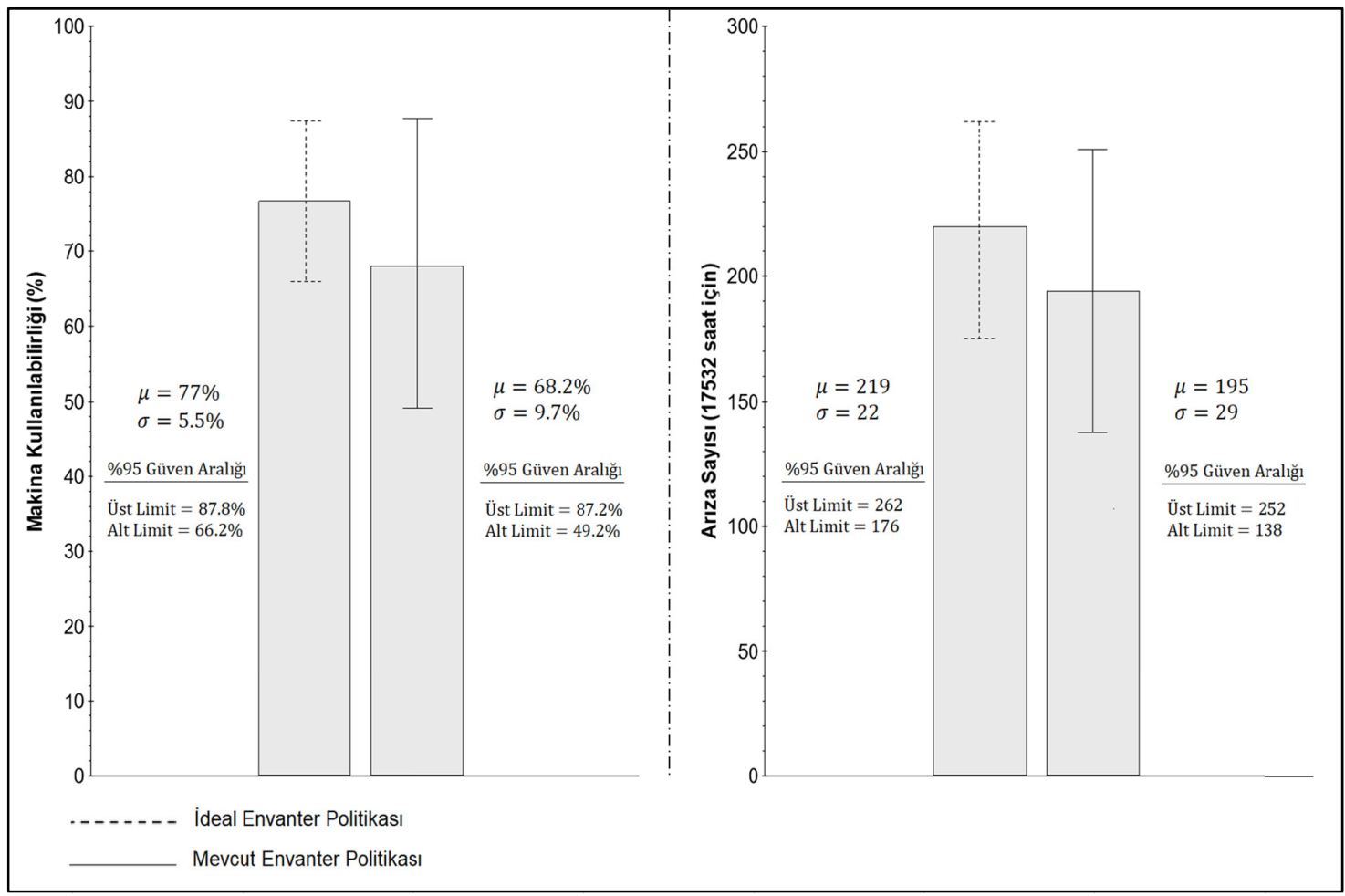

Şekil 3. Makina kullanılabilirliği ve arıza sayısına etkisi 


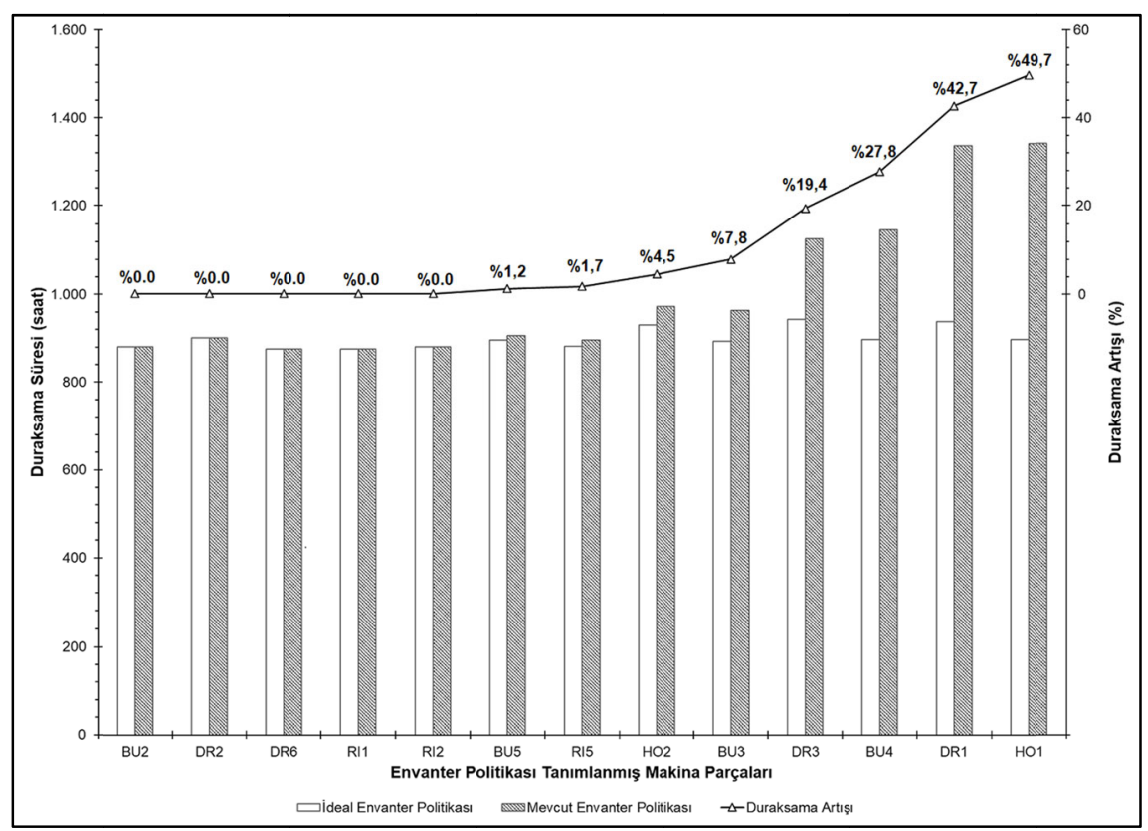

Şekil 4. Parça bazlı duraksamalardaki değişimler (\%)

Algoritma, makina parçalarının arızalanma ve tedarik süreçlerini hesaba katarak envanterden giriş ve çıkışları parça bazlı olarak kaydetmektedir. Buna göre hedef gözlem süresi içerisinde kullanılan parçalar ve ortalama depolanmış parçalar hakkında bilgiler Şekil 5'te verilmiştir. İlgili çıktılar, ilk stok seviyeleri ve yeniden sipariş adetlerinin değerlendirilmesi hususunda yararlanılabilir.

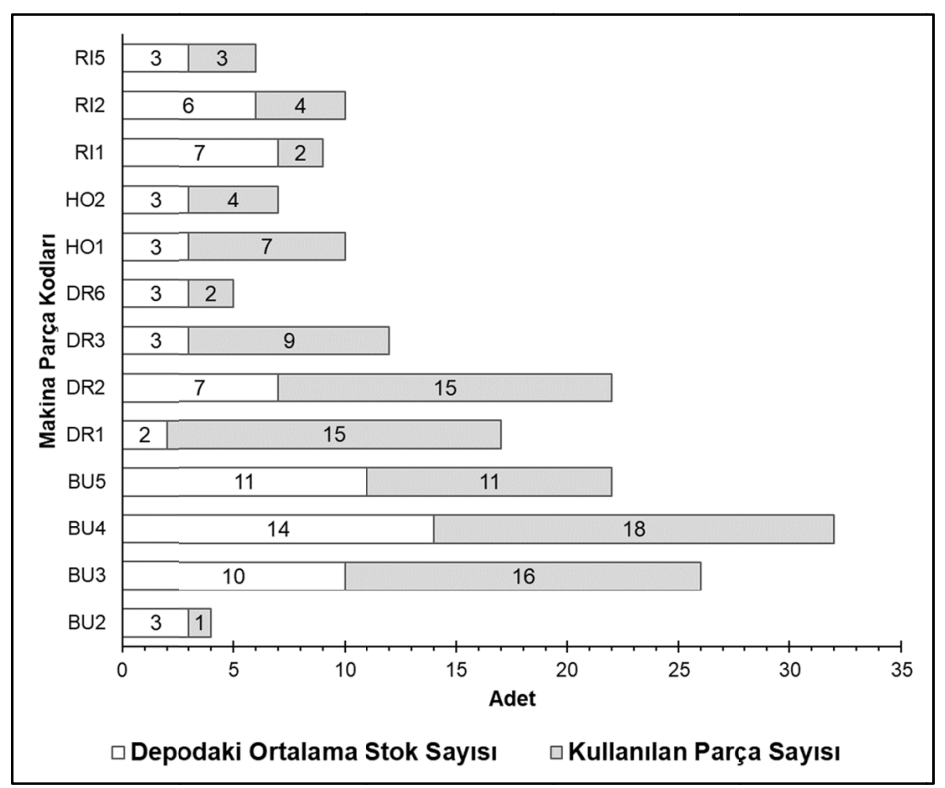

Şekil 5. Makina parçalarına ait yedek parça envanter istatistikleri 


\section{TARTIŞMA}

Geliştirilen algoritmanın sektördeki faal envanter politikalarına uygulanabilirliğini değerlendirirken, ilgili makina parçaları arasındaki fonksiyonel bağımlılıkların ve ilgili bakım-onarım ve envanter politikalarının çalışmadaki varsayımlara uygun olması gerekmektedir. Çalışma içerisinde, makina parçalarının çalışabilirlikleri arasında doğrudan bir bağımlılık olduğu varsayılmıştır. Böylelikle, makina içerisindeki kritik çalışır parçaların herhangi bir tanesinde bakım-onarım gereksinimi ortaya çıktığında, bütün makinanın üretimini durmaktadır. İkinci olarak, bakım-onarım ekibi yetkinliği ve yeterliliğine yönelik hususlar model içerisinde dikkate alınmamıştır. Bu hususların, mevcut ve ideal envanter modellerinde yakın etkiler yaratacağı ve çalışma bulgularını değiştirmeyeceği düşünülmüştür. Ek olarak, algoritma içerisinde $(\mathrm{Q}, \mathrm{R})$ envanter politikası, yani belirli bir sipariş seviyesinde sabit sayıda tedarikte bulunulmasına yönelik bir politika dikkate alınmıştır. Bu yedek parça envanter politikası, özellikle madencilik ve ağır iş makinası kullanımı olan diğer üretim sektörlerinde sıklıkla kullanılmaktadır. Bu politikanın, makina-yoğun faaliyetler için yedek parça temini sürecinde kolay uygulanabilir olduğu gözlenmektedir.

Çalışma varsayımlarına uygun şekilde yürütülen örnek çalışmada, bir madende kullanılan yer kazarın parçaları için uygulanan bir $(\mathrm{Q}, \mathrm{R})$ envanter politikası incelenmiştir. Pratiklik açısından, ilgili madende yeniden sipariş verilmesi için limit değerlerin $(\mathrm{R})$ ve sipariş adetlerinin (Q) eşit olarak alındığı gözlenmiştir. Çalışma çıktıları, bakım-onarım ve envanter gereksinimleri arasında doğrudan bağlantı kurulanabilen belirli parçaların makina kullanılabilirliğine etkisini ortaya koymaktadır. Diğer bir yandan, geliştirilen bu algoritma, rassal arıza davranışlarının izlenebilmesine olanak sağlamaktadır. Elde edilen sonuçların, gerçek arıza davranışına göre karşılaştırmalı olarak değerlendirilmesi simülasyonun doğrulanmasına fayda getirecektir. Böylelikle, farklı yedek parça politikaları ve makina arızalanma profili arasındaki ilişki detaylı şekilde incelenebilmektedir.

\section{SONUÇLAR}

Maden makinaları, zorlu çalışma ortamlarında değişken üretim miktarlarına göre faaliyet göstermektedirler. Bu makinalar genellikle yüksek üretim kapasitelerine sahip olup, arıza veya diğer sebeplerden kaynaklı duraksamalarda oluşacak üretim kayıpları, bu makinaların operasyon içerisindeki önem ve telafi edilebilirliğine göre değișiklikler göstermektedir. Özellikle, kazı faaliyetini yürüten makinalarda meydana gelecek duraksamalar tüm maden üretime doğrudan etki edebilmektedir. Arızaya bağlı duraksamalar, makinanın çalışan parçalarının zaman içerisindeki yıpranmaları ve bu parçaların arızalanma sıklığına göre farklılıklar gösterir. Bu nedenle, uygulanacak bakım-onarım politikası ve bu politikanın tamamlayıcısı olan yedek parça envanter politikası, makinaların güncel davranışlarına yönelik hazırlanmalı veya tekrardan değerlendirilmelidir. $\mathrm{Bu}$ bağlamda, arıza kayıtlarının hassas ve açıklayıcı olarak tutulması ve arıza artışlarının incelenmesi, yedek parça önceliklerinin ve önemlerinin belirlenmesi ve periyodik olarak yedek parça envanter politikasının verimliliğinin analiz edilmesi üretimdeki kayıpları azaltacaktır. Aksi bir durumda, yedek parçanın gereğinden fazla depolanması ve/veya parçanın gerekli durumlarda stokta bulunmaması gibi istenmeyen olaylar yaşanılabilir.

Bakım-onarım esnasında yaşanılabilecek yedek parça yokluğu, tüm madencilik faaliyetlerine ve nihai üretim hedeflerine büyük etkilerde bulunabilir. Bu çalışma kapsamında, mevcut bir envanter politikasının makina kullanılabilirliğine muhtemel negatif etkilerini analiz edebilen bir simülasyon algoritması geliştirilmiştir. $\mathrm{Bu}$ algoritma, bir sistemin çalışan parçalarının rasgele arıza ve çalışma davranışı sergilemesine ve envanter durumunun zamana göre izlenmesine olanak sağlamaktadır. Örnek bir uygulamada, 
geliştirilen bu algoritma bir çekme kepçeli yerkazara uygulanmıştır. Bu uygulama içerisinde, makinanın arıza davranışı ve kullanılabilirliği, hem bağımsız olarak hem de yedek parça envanter politikası ile etkileşime geçirilerek analiz edilmiştir. Simülasyon sonuçları, mevcut envanter modelindeki iyileştirmeler ile makina kullanılabilirliğinin \%9 oranında arttırılabileceğini göstermiştir.

\section{KAYNAKLAR}

1. Samal, N.K., Pratihar, D.K., 2015. Joint Optimization of Preventive Maintenance and Spare Parts Inventory using Genetic Algorithms and Particle Swarm Optimization Algorithm. International Journal of Systems Assurance Engineering and Management, 6(3), 248-258. doi:10.1007/s13198-015-0349-3

2. Panagiotidou, S., 2014. Joint Optimization of Spare Parts Ordering and Maintenance Policies for Multiple Identical Items Subject to Silent Failures. European Journal of Operational Research, 235(1), 300-314. doi:10.1016/j.ejor.2013.10.065

3. Taleizadeh, A.A., Niaki, S.T.A., Barzinpour, F., 2011. Multiple-buyer Multiple-vendor Multi-product Multi-constraint Supply Chain Problem with Stochastic Demand and Variable Lead-time: A Harmony Search Algorithm. Applied Mathematics and Computation, 217(22), 9234-9253. doi:org/10.1016/j.amc.2011.04.001

4. Panagiotidou, S., 2019. Joint Optimization of Spare Parts Ordering and Age-Based Preventive Replacement. International Journal of Production Research, 1-17. doi: 10.1080/00207543.2019.1677959

5. Kader, B., Sofiene, D., Nidhal, R., Walid, E., 2013. Jointly Optimal Preventive Maintenance under Spare Parts Order Strategy. IFAC Proceedings Volumes, 46(9), 1376-1380. doi: 10.3182/20130619-3-RU-3018.00088

6. Bounou, O., El Barkany, A., El Biyaali, A., 2017. Inventory Models for Spare Parts Management: A Review. In International Journal of Engineering Research in Africa
Trans Tech Publications Ltd. (28, 182-198) doi: 10.4028/www.scientific.net/JERA.28.182

7. Ghodrati, B., Kumar, U., 2005. Operating Environment-Based Spare Parts Forecasting and Logistics: A Case Study. International Journal of Logistics: Research and Applications, $\quad$ 8(2), 95-105. doi:10.1080/13675560512331338189

8. Ghodrati, B., Akersten, P.A., Kumar, U., 2007. Spare Parts Estimation and Risk Assessment Conducted at Choghart Iron Ore Mine: A Case Study. Journal of Quality in Maintenance Engineering, 13(4), 353-363. doi:10.1108/13552510710829452

9. Wang, L., Chu, J., Mao, W., 2009. A Condition-Based Replacement and Spare Provisioning Policy for Deteriorating Systems with Uncertain Deterioration to Failure. European Journal of Operational Research, 194, 184-205. doi:10.1016/j.ejor.2007.12.012

10. Louit, D., Pascual, R., Banjevic, D., Jardine, A., 2011. Optimization Models for Critical Spare Parts Inventories-A Reliability Approach. Journal of the Operational Research Society, $\quad 62, \quad 992-1004$. doi:10.1057/jors.2010.49

11. Martínez, A., Pascual, R., Maturana, S., 2016. A Methodology for Integrated Critical Spare Parts and Insurance Management. Applied Stochastic Models in Business and Industry, 32(1), 90-98. doi:10.1002/asmb.2125

12.Zhang, Q., Lv, X., Shi, J., 2017. Research on Inventory Sharing Model of Frequent Mining Machinery Maintenance Spare Parts. Proceedings of $12^{\text {th }}$ IEEE Conference on Industrial Electronics and Applications, 1224-1229. Siem Reap: IEEE. doi:10.1109/ICIEA.2017.8283026

13. Qarahasanlou, N., Barabadi, A., Ataei, M., Einian, V., 2019. Spare Part Requirement Prediction Under Different Maintenance Strategies. International Journal of Mining, Reclamation and Environment, 33(3), 169182. doi:10.1080/17480930.2017. 1373883

14. Reliasoft RenoC [Bilgisayar Yazılımı], 2019. Arizona, Tuscon.

15. Rossetti, M. D., 2015. Simulation Modeling and Arena. John Wiley \& Sons, New Jersey. 
Yedek Parça Envanter Politikasının Makina Kullanılabilirliğine Etkisinin Bir Simülasyon Algoritmasıyla İncelenmesi

16. Golbasi, O., Demirel, N., 2017. A CostEffective Simulation Algorithm for Inspection Interval Optimization: An Application to Mining Equipment. Computers \& Industrial Engineering, 113, 525-540. doi:10.1016/ j.cie. 2017.09 .002 